\title{
Teknik Analisis Serpih Bilah
}

\section{Indah Asikin Nurani}

Keywords: lithic, stone tools, technique, analysis, method, theory

\section{How to Cite:}

Nurani, I. A. (2000). Teknik Analisis Serpih Bilah. Berkala Arkeologi, 20(1), 26-39. https://doi.org/10.30883/jba.v20i1.804

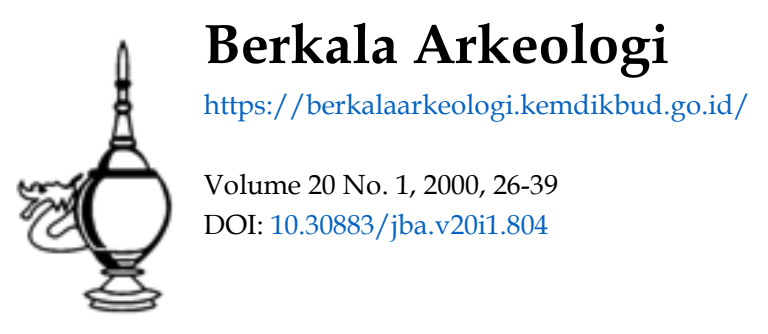

\section{(c) (1) (2)(2)}

This work is licensed under a Creative Commons Attribution-NonCommercial-ShareAlike 4.0 International License. 


\title{
TEKNIK ANALISIS SERPIH BILAH
}

\author{
Indah Asikin Nurani \\ (Balai Arkeologi Yogyakarta)
}

\section{Teknik Pendataan}

Dalam teknologi alat-alat batu prasejarah, Indonesia memiliki proses perkembangan yang identik dengan perkembangan teknologi alat batu secara umum, dari bentuk sederhana menuju bentuk yang lebih kompleks dan sempurna. Proses perkembangan tersebut dalam dimensi waktu merupakan suatu proses evolusi teknologis yang cukup panjang yang dikenal dengan istilah paleolitik (batu tua), mesolitik (batu madya), dan neolitik (batu muda). Peristilahan tersebut tidak menunjuk pada konotasi suatu periode (masa), tetapi hanya merupakan terminologi teknologis (Soejono, 1981).

Teknologi alat batu, dalam garis besarnya dilandasi oleh dua faktor, yaitu metode dan teknik. Metode berada pada bentuk fikiran, sedangkan teknik berada di kedua belah tangan. Metode pembuatan alat merupakan suatu tatanan yang dijalankan secara sistematis dan teratur dan bukan merupakan sesuatu yang terjadi secara kebetulan. Demikian pula halnya dengan ciri-ciri teknologis seperti dataran pukul (strikingplatform), bulbus (bulb of percussion), tatu penyerpihan (bulbar scar), dan alur penyerpihan (ripples) merupakan akibat dari teknologi pembuatan yang diterapkan oleh si pembuat (Crabtree dalam Widianto, 1984). Cara pembuatan alat-alat batu dengan teknik yang sama dan berlangsung selama ratusan tahun tersebut telah menghasilkan bentuk dan ciri-ciri teknologis yang sama di berbagai tempat di dunia.

\section{A. Terminologi Serpih Bilah}

Alat-alat batu yang digolongkan ke dalam serpih bilah adalah alat-alat non masif yang secara teknologis menunjukkan ciri kuat tentang pelepasan dari batu inti oleh manusia. Ciri teknologis hasil tangan manusia adalah eksistensi bulbus-bulbus negatif pada bagian dorsal, bagian ventral tanpa faset, dan adanya dataran pukul. Ciri seperti ini sering kali bertambah ragamnya yang diakibatkan oleh ketahanan jenis dan sifat batuan terhadap pukulan yang keras oleh manusia saat alat serpih dilepaskan dari batu inti, seperti adanya kerucut pukul (bulbus), tatu penyerpihan (bulbar-scar), alur penyerpihan (ripples), dan retak-retak penyerpihan (fissures). Ciri-ciri terakhir tersebut akan ada pada alat serpih yang dibuat dari bahan dasar berkualitas tinggi, seperti proses silikaan lanjut dengan butiran halus. 
Selain ciri-ciri teknologis tersebut, pelepasan alat-alat serpih bilah dari batu inti dapat dilakukan dengan pukulan langsung (direct-percussion) dan tidak langsung (indirectpercussion). Faset-faset (bulbus negatif) pada bagian dorsal dibentuk terlebih dahulu, kemudian diikuti dengan pembuatan dataran pukul, dan dengan menggunakan perforator dipukul dengan keras untuk melepaskan alat-alat serpih ini dari batu inti. Umumnya bagian ventral dibiarkan polos, tanpa dilakukan penghalusan melalui pemangkasan kedua (secondary retouched), namun ada juga yang dilakukan pemangkasan kedua terutama pada jenis alat lancipan dan mata panah yaitu untuk membentuk tajaman.

Sebagaimana telah diuraikan di atas bahwa serpih bilah merupakan alat yang berkembang sejak teknik tertua yaitu paleolitik sampai teknik termuda yaitu neolitik, berikut akan diuraikan mengenai kekhasan teknologi sehubungan dengan perkembangan pembuatan serpih bilah.

\section{Paleolitik}

Alat-alat serpih bilah pada teknologi paleolitik merupakan serpih bilah dengan teknik paling sederhana yaitu masih menonjolkan pembuatan alat melalui teknik pemangkasan (chipping) dan penyerpihan (flaking). Teknik pemangkasan dilakukan pada satu muka (monofasial) ataupun dua muka (bifasial). Alat-alat serpih bilah pada tingkat teknologi ini, lebih sering diterapkan teknik penyerpihan saja dengan produk utamanya berupa alat serpih (flake), bilah (blade), dan serut (scraper).

\section{Mesolitik}

Pada tingkat teknologi mesolitik, sebagian produk alat batu tingkatan paleolitik masih dipertahankan dan diteruskan dengan peningkatan yang lebih cermat pada teknik pembuatan dan variasi produknya. Peningkatan lebih lanjut dan cermat lebih ditujukan pada pemangkasan dan menonjolnya penyerpihan kedua (secondary-retouched). Produk teknologi pada tingkatan ini lebih bervariasi yaitu selain variasi yang lebih berkembang dari tipe serpih, bilah, dan serut, muncul tipe lain berupa laneipanlancipan mikrolit dan mata panah sederhana.

\section{Neolitik}

Tingkatan teknologi ini memiliki perkembangan yang lebih lanjut dan cermat dibanding tingkatan mesolitik yaitu melalui pemangkasan yang lebih kompleks. Ciri yang menonjol adalah adanya penghalusan (grinding) dan pengupaman (polishing), produk serpih bilah pada tingkatan ini antara lain adalah lancipan, mata panah, dan gurdi. Pada tingkatan teknologi ini diimbangi dengan pola hidup yang sudah mengenal eocok tanam, sehingga produk yang dihasilkan menunjukkan adanya pemanfaatan dalam aktivitas bertani, seperti lancipan, mata panah dengan berbagai 
jenis seperti berdasar bundar, bergerigi, dan sudah dibentuk suatu perbengkelan yang menyebabkan ditemukannya tatal-tatal batu sebagai limbah pembuatan alat.

\section{B. Perolehan Data}

Serpih bilah merupakan alat batu yang sering ditemukan pada situs-situs prasejarah baik di gua hunian (situs tertutup) maupun pada bentang lahan terbuka. Lebih lanjut tentang karakter industri litik ini, Truman Simanjuntak (1994) menyatakan adanya kekhususan dari tinggalan-tinggalan litik sehubungan dengan tingkat teknologinya. Tinggalan paleolitik menempati bentang alam terbuka atau di sepanjang daerah aliran sungai. Sisa-sisa budaya mesolitik lebih cenderung terkonsentrasi pada situs-situs ceruk atau gua. Sedangkan unsur-unsur neolitik kembali menempati bentang alam terbuka. Dalam perolehan data, berdasarkan pada asumsi tersebut dapatlah dilacak lebih lanjut secara sistematis baik melalui survei maupun ekskavasi.

Aktivitas survei dapat dilakukan dengan memploting data permukaan ke dalam peta. Sedangkan dalam ekskavasi dapat dilakukan dengan membuat grid pada lahan yang merupakan areal penelitian. Hal tersebut dimaksudkan untuk mempermudah pengidentifikasian berkaitan dengan aspek kontekstual dan pola sebaran yang ada.

\section{Langkah-langkah Teknis Analisis Serpih Bilah}

Dalam pembuatan serpih bilah dikenal adanya konsep rangkaian operasional yang meliputi kesatuan operasi teknis menurut proses dinamis pada tahapan operasional secara kronologis. Tahapan ini meliputi pencarian bahan baku, pembentukan bahan baku dan pelepasan serpihan untuk menghasilkan support alat, dan akhirnya tahapan pengerjaan melalui peretusan dan pemakaian alat. Untuk mengetahui dan mengkaji keseluruhan prosesi rangkaian operasional tersebut, perlu dijabarkan variabel-variabel yang harus diukur dalam menganalisis serpih bilah secara detil. Selanjutnya akan didapat interpretasi yang lebih akurat dan lebih berbobot.

\section{A. Kualitatif (tipe alat)}

Kajian kualitatif adalah indentifikasi secara kualitas dalam penentuan tipe-tipe serpih bilah yang didasarkan pada aspek teknologis ataupun aspek morfologis. Serpih bilah merupakan alat litik berukuran kecil (non masif) yang memiliki beberapa tipe dengan karakter masing-masing, beberapa tipe serpih bilah yang sering ditemukan pada situssitus prasejarah dapat diuraikan sebagai berikut (diacu dengan referensi : Crabtree, 1984; Movius, 1948; Simanjuntak, 1995). 
Tipe alat serpih (flake) terdiri atas dua tipe yaitu serpih tanpa retus dan serpih dengan retus pemakaian. Serpih tanpa retus pada umumnya memiliki ciri-ciri teknologis yang lengkap sebagai hasil pengerjaan manusia, yaitu hadirnya dataran pukul, bulbus, dan terkadang luka pukul. Bentuknya bervariasi sebagaimana juga ukurannya. Sedangkan serpih dengan retus memiliki ciri-ciri teknologis, morfologis, dan metrik yang sama dengan serpih tanpa retus. Perbedaannya hanya terletak pada kehadiran retus di bagian tertentu dari sisinya, retus-retus tersebut merupakan bekas-bekas pengerjaan penyempurnaan agar sisi tersebut lebih "efficace" dalam pemakaiannya.

Bilah (blade) secara teknologis sama dengan serpih, perbedaan yang mendasar antara alat serpih dengan bilah adalah pada bentuk alat atau dari aspek morfologisnya saja. Alat serpih berbentuk pipih melebar, sedangkan bilah berbentuk memanjang dengan ukuran panjang minimal 2 kali ukuran lebarnya. Kedua sisi panjang umumnya bertemu di ujung dan membentuk lancipan. Bagian ventral dibiarkan polos tanpa faset namun ada juga yang dipangkas lagi dengan satu pangkasan memanjang untuk penipisan. Sedangkan bagian dorsal biasanya dipangkas melalui faset-faset penyerpihan yang sudah dipersiapkan. Pada bagian dorsal umumnya didominasi oleh pangkasan memanjang yang membentuk punggung alat dengan penampang irisan transversal berbentuk segitiga.

Serut (scraper) adalah alat yang telah dipakai, yang tidak menunjukkan ciri teknologis seperti yang ditunjukkan oleh alat serpih dan bilah. Unsur pemakaian dan ukuran alat yang tergolong alat nonmasif merupakan kriteria terpenting untuk kategori alat ini. Tidak ada pembentukan melalui pemangkasan ataupun penyerpihan untuk memperoleh bagian tajamannya. Oleh karena itu, serut dapat berupa serpihan-serpihan batu ataupun sekedar batu alam yang kemudian dipakai. Tidak adanya kriteria yang mendasar untuk masalah teknologis ini menyebabkan kemungkinan bergantinya kategori serut apabila dihadapkan pada ukuran alat besar (alat masif) yang dikategorikan sebagai kapak perimbas. Berdasarkan pada kriteria unsur pemakaian inilah, maka dalam tipe alat serut muncul tipe-tipe lain yang ditunjukkan pada keletakan retus atau unsur pemakaian. Adapun tipe-tipe serut meliputi serut ujung, samping, bergigir, cekung, cembung, dan sebagainya.

Serut samping (side scraper) dicirikan oleh keberadaan retus yang teratur menutupi sebagian besar atau seluruh sisi alat. Beberapa alat tipe ini terdapat pengerjaan retus secara intensif sampai menutupi sebagian alat, bahkan seluruh keliling alat. Tipe ini apabila berukuran kecil disebut serut samping kecil (raclette). Serut gigir (denticulated) dicirikan pada tipe klasik dan cenderung tebal. Berdasarkan sudut jumlah cekungan, serut ini dapat dikelompokkan menjadi serut gigir sederhana (lurus, cembung, atau cekung), serut gigir ganda (kedua sisi lateral diretus dengan cekungancekungan), dan serut gigir transversal (cekungan pada sisi distal, tegak lurus pada sumbu morfologi). Selain itu didasarkan pada tepian cekungan dapat dikelompokkan 
dalam cekungan bersambung berbentuk runcing dan membulat dan cekungan secara menyebar. Serut cekung (notch) dicirikan oleh keberadaan satu atau dua cekungan dan banyak cekungan yang dibentuk tidak bersambung. Cekungan dapat berupa "mikro retus" (retus cenderung kecil dan terbatas pada tepian alat) atau "clactonian" (cekungan besar melalui peretusan tunggal). Kedua cekungan tersebut merupakan aspek teknis yang tidak berkaitan dengan aspek pemakaian. Serut ujung umumnya berukuran tebal, masif, dibentuk secara teratur melalui retus samping memanjang lurus "lamellaire" dan berjenjang, dan sering sangat terjal.

Limace dicirikan oleh morfologi tebal dengan irisan plano-konveks menyerupai lancipan ganda. Umumnya memiliki retus pada keseluruhan sisinya, dataran pukul sering tidak tampak oleh peretusan atau sering sama sekali dihilangkan. Ciri lain dari alat ini tergolong sangat tebal, berbentuk simetris, dan kerap menyimpan korteks di bidang dorsal.

Pisau berpunggung (natural backed knife) merupakan alat serpih tebal berbentuk persegi atau segitiga sebagai produk awal, seperti ditampakkan oleh korteks di bidang dorsal atau serpih pangkasan pertama (first cortical flake). Tipe support dengan korteks sangat menonjol dimana sisi distal memiliki retus pemakaian dan sering sejajar pada bidang korteks.

Bor merupakan alat di mana pada bagian tertentu (umumnya di sisi distal) terdapat bagian meruncing yang dibentuk secara sengaja. Pada umumnya bentuk dasar runcingan telah tercipta pada serpih, melalui persiapan-persiapan awal sebelum pemisahan dari batu inti. Bentuk dasar ini kemudian disempurnakan melalui peretusan sisi atau pembuatan cekungan pada kedua sisi runcingan. Letak runcingan dapat melahirkan beberapa bentuk bor, adakalanya terletak pada salah satu sudut dengan arah runcingan menyilang terhadap sumbu morfologi alat. Selain itu letak runcingan ada juga di bagian tengah sisi distal bertumpu pada sumbu-sumbu morfologi alat. Sering pula runcingan dibuat dengan mengerjakan salah satu sisi lebih intensif dari sisi lain sehingga melahirkan bentuk khas melengkung. Tipe bor terdiri atas tipe khas (typical), kurang khas (atypical), dan tipe tidak khas. Atypical merupakan alat yang pada sisi distal atau kedua sisi runcingnya tidak diretus seluruhnya, atau melalui pangkasan yang menghasilkan bentuk runcingan asimetris. Panjang runcingan alat relatif pendek. Typical merupakan bor klasik dan kecil (prickle) yang sering miring dengan arah runcingan menyilang terhadap sumbu morfologi (angle piercer) alat. Bor yang tidak khas dicirikan oleh runcingan yang berbentuk miring melengkung menyerupai paruh burung.

Lancipan merupakan alat yang memiliki persamaan dengan bor, hal yang membedakannya adalah keadaan runcingannya. Pada alat lancipan, bagian yang runcing selalu di bagian distal dan diciptakan secara berstruktur dalam arti pengerjaan 
yang teratur mulai dari bagian pangkal hingga bagian ujung. Dalam hal ini suatu lancipan akan cenderung menyempit secara teratur dari bagian proksimal ke arah distal. Pada umumnya bentuk lancipan mengarah pada segitiga dengan tinggi (panjang) melebihi dasar (lebar). Pembentukan lancipan dilakukan dengan pemangkasan-pemangkasan sekunder pada kedua sisi lateral hingga membentuk runcingan di bagian distal. Terkadang suatu bentuk dasar segitiga sudah tercipta dikala pelepasan serpih dari batu intinya, sehingga pengerjaan selanjutnya tinggal penyempumaan untuk menghasilkan bentuk final.

Gurdi (borer) secara teknologis umumnya menunjukkan pada teknologi serpih bilah yang kemudian pada kedua sisi lateralnya dipangkas memusat ke arah distalnya, sehingga diperoleh bentuk runcing pada ujung alat (yang berlawanan dengan dataran pukulnya). Untuk mendapatkan bentuk lancipan yang sempurna, kedua sisi lancipan mengalami pemangkasan kedua.

Mata panah memiliki ciri-eiri berbentuk segitiga dengan tinggi melebihi lebar, sering sisi yang satu lebih panjang dari sisi lain, sehingga melahirkan bentuk asimetris. Dasar cekung dihasilkan melalui pangkasan bifasial. Umumnya tebal dengan irisan berbentuk ellips di mana kedua bidang cembung oleh pengerjaan (retus) yang sangat intensif dan teratur. Sayap simetris sering meruncing, sisi lateral dikerjakan halus mengarah pada bentuk gerigi atau rata.

\section{B. Kondisi}

Kondisi serpih bilah pada saat ditemukan baik melalui ekskavasi terlebih melalui survei sering dihadapkan pada kondisi yang tidak asli lagi. Hal tersebut disebabkan serpih bilah telah mengalami proses abrasi yang disebabkan oleh transformasi ataupun patinasi. Berdasarkan hal itu, maka untuk mengetahui kondisi serpih bilah harus diketahui hal-hal berkaitan dengan beberapa variabel kondisi yang meliputi tingkat pembundaran, patinasi, warna, dan bahan batuan yang digunakan sebagai alat. Variabel-variabel tersebut sangat menentukan kondisi serpih bilah pada saat ditemukan.

Pembundaran (rounded) pada alat litik sering terjadi, karena sebagian besar alat litik terutama hasil temuan survei permukaan ditemukan pada daerah aliran sungai ataupun pada lingkungan alam yang masih aktif. Hal tersebut disebabkan oleh proses abrasi, transformasi, maupun patinasi. Berdasarkan hal tersebut, proses pembundaran bisa menyebabkan hilangnya atau pudarnya pangkasan-pangkasan ataupun kaburnya perimping-perimping bekas pakai pada sisi tajamannya. Untuk itu perlu diketahui ada tidaknya dan ringan, sedang atau beratnya pembundaran pada serpih bilah. Berkaitan dengan pembundaran, proses patinasi dapat juga terjadi pada serpih bilah saat 
ditemukan. Untuk itu perlu diketahui ada tidaknya patinasi pada alat. Jika ada patinasi, maka perlu diketahui tingkatan patinasi tipis, sedang atau tebal.

Berdasarkan pola hidup manusia penghasil serpih bilah masih pada tingkat peramu dan pengumpul makanan, maka umumnya konteks temuan serpih bilah berada pada perapian. Dengan demikian, berkaitan dengan kondisi alat perlu diketahui ada tidaknya bekas bakar pada serpih bilah. Selain itu kondisi serpih bilah juga perlu diketahui tentang keadaan alat apakah utuh atau berupa pecahan, dan baik rapuhnya kondisi fisik alat.

Bahan baku dalam hal ini batuan, sangat menentukan kualitas produk industri litik. Untuk itu dalam pemilihan bahan untuk pembuatan alat, hal-hal yang perlu dipertimbangkan antara lain meliputi (Greisser and Payson D. Sheets, 1979): (a) kekerasan (istilah kekerasan ada dua yaitu hardness dan taughness. Hardness yaitu daya tahan untuk mengalami perubahan bentuk secara permanen, sedangkan toughness merupakan daya tahan untuk mengalami keretakan); (b) kerapuhan; (c) kekenyalan atau elastisitas (resiliency) yaitu kemampuan untuk kembali ke bentuk semula setelah ditekan atau direnggangkan); dan (d) kemudahan untuk diserpih (sifat ini berhubungan dengan homogenitas bahan, sehingga memungkinkan pembuat alat untuk memukul bahan dari segala arah). Bahan batuan yang dianggap memenuhi keempat hal tersebut adalah batuan yang bertekstur crypotocrystalline (memiliki butiran kristal penyusunnya sangat halus $\pm 0.01 \mathrm{~mm}$ ), isotropic (batuan yang mempunyai sifat sama di seluruh bagian batuan), dan mengandung kadar silika tinggi.

Pemilihan bahan dengan kandungan silika tinggi disebabkan pada sifat silika. Silika $\left(\mathrm{SiO}_{2}\right)$ merupakan senyawa antara silikon dan oksigen. Silika terdapat di mana-mana dalam mineral silikat yang membentuk batuan dan merupakan bagian utama kerak bumi. Dalam silikat, silika bersenyawa atau bercampur dengan aneka senyawa lain. Dalam kuarsa dan beberapa mineral lain, silika berada sendirian. Silika mempunyai bentuk kristalin (koesit, kristabolit, kuarsa, dan stishovit) dan amorf (lechatlierit, opal, dan lain-lain). Kuarsa merupakan bentuk paling umum dari silika kristalin.

Beberapa bahan yang sering digunakan untuk pembuatan alat yang mengandung silika atau biasa disebut kersikan baik dalam kadar tinggi maupun rendah seperti bahanbahan berikut. Kuarsa merupakan batuan beku yang kaya akan silika dan alumina, jernih, tak berwama, kadang-kadang berwarna putih susu atau kelabu. Obsidian merupakan batuan beku luar (extrusive igneous rock) gelas volkanik masif yang mempunyai pecaharı conchoidal, berwarna cerah dan berkilap gelas, jika banyak mengandung magnetite dan masic mineral lain akan berwarna hitam. Kadang-kadang berwarna kuning, merah, atau coklat karena magnetite dan hematite. Gamping kersikan termasuk batuan sedimen non klastik yang mineral penyusunnya berupa kalsit, dan bertekstur medium grained (1/16-2 mm) sampai coarse grained (lebih dari 
$2 \mathrm{~mm}$ ). Selain itu jenis kalsedon lainnya adalah jasper, tidak tembus cahaya, dan warnanya bervariasi.

Chert atau batu api merupakan kuarsa $\left(\mathrm{SiO}_{2}\right)$ dalam bentuk butiran halus. Kuarsa ini dikenal sebagai batu api, karena bila diadu dengan baja atau batu lain akan memercikkan bunga api yang dapat membakar selulosa kering. Dalam klasifikasi batuan termasuk batuan sedimen non klastik yang tersusun atas mineral kalsedon, dan tidak tembus cahaya. Umumnya bagian dalam berwarna lebih gelap daripada lapisan luar. Chert atau rijang (istilah lokal) mudah dipangkas dan dibentuk, dengan serpihan yang cenderung mempunyai sisi yang tajam. Jenis batuan ini sangat umum digunakan dalam industri alat batu prasejarah.

Basal( $t$ ) merupakan batuan beku berwarna gelap, berbutir halus yang umumnya dari pembekuan lava gunungapi, terutama gunungapi di tengah samudera. Mineral pembentukannya adalah plagioklas dan piroksen serta sedikit olivin. Basal sangat sulit dikerjakan untuk menghasilkan alat yang baik. Sifatnya yang kasar membuat serpihbilah yang dihasilkan sangat jarang memiliki sisi yang tajam. Kekasarannya pula yang membuat sulit untuk menciptakan berbagai bentuk dan tajaman seperti yang diinginkan si pembuat.

\section{Morfologi}

Morfologi yang perlu diinformasikan dalam analisis serpih bilah adalah bentuk fisik serpih dari berbagai bagian. Kerangka alat serpih terdiri atas 5 bagian yaitu bagian dorsal, ventral, proksimal, distal, dan lateral. Dorsal merupakan bagian punggung alat, yaitu bagian yang biasanya dikerjakan terlebih dahulu sebelum dilepaskan dari batu inti. Ventral merupakan bagian dalam pada batu inti sebelum dilepaskan, biasanya bagian ini dibiarkan polos. Hal-hal yang sering terdapat pada ventral lebih disebabkan oleh kualitas bahan yaitu berupa bulbus, dataran pukul, alur penyerpihan, tatu penyerpihan, atau retak-retak penyerpihan. Proksimal adalah bagian bawah atau dasar alat, distal bagian tajaman, sedangkan lateral adalah bagian sisi kanan maupun kiri alat. Sebagaimana telah disinggung dalam tipe-tipe alat, maka masing-masing bagian tersebut menunjukkan adanya pengerjaan baik pengerjaan tahap awal maupun tahap lanjutan dengan melakukan pemangkasan kedua.

Dalam menginformasikan bentuk fisik serpih terdiri atas bentuk, penampang, dan ada tidaknya korteks. Bentuk serpih bilah meliputi bentuk membulat, bujursangkar, persegi panjang, segitiga, trapesium, segilima, atau tidak beraturan. Penampang serpih meliputi bulat, lonjong, bujursangkar, persegi panjang, segitiga, trapesium, atau tidak beraturan. Adapun ada tidaknya korteks (kulit batu) akibat pengerjaan dapat diinformasikan tentang keberadaan korteks tersebut. Adanya korteks bisa terdapat 
pada bagian distal, proksimal, ventral, dorsal, ventral-dorsal, dorsal-lateral, lateral kiri, ataupun lateral kanan. Bagian lateral baik kanan maupun kiri dapat berbentuk cembung, cekung, lurus/datar, atau bergerigi. Sedangkan bagian proksimal dapat berbentuk cekung, lurus, miring, atau bergerigi. Bagian tajaman atau distal dapat berbentuk cembung, cekung, lurus/datar, atau nuncing.

\section{Teknologi}

Teknologi pembuatan serpih bilah, sebagaimana telah disinggung di atas menunjukkan adanya ting-katan pengerjaan baik dikerjakan pada tahap awal ataupun tahap pengerjaan lanjutan. Dalam teknologi serpih bilah ini hal-hal yang perlu diidentifikasi adalah tingkatan pengerjaan dalam beberapa tahapan tersebut. Berikut akan diuraikan tahapan pengerjaan alat serpih bilah secara keseluruhan (diacu dengan referensi : Sutton dan Brooke S. Arkush, 1996; Hodges, 1964; Movius, 1948; Widianto, 1981).

Pengerjaan awal dalam pembuatan alat serpih bilah setelah tersedianya bahan baku adalah pemangkasan pada bagian batu inti baik pengerjaan yang sudah dipersiapkan maupun tidak. Pengerjaan awal setelah lepas dari batu inti inilah yang disebut bagian dorsal. Jumlah pangkasan dapat diketahui tingkat teknologi yang diterapkan. Sesuai dengan tujuan pembuatan alat serpih bilah dalam berbagai tipe alat, maka pangkasan pada batu inti ini biasanya sudah dipersiapkan terlebih dahulu sesuai jenis alat yang dikehendaki. Tahap selanjutnya adalah pelepasan dari batu inti, bagian dalam sebelum terlepas dari batu inti inilah yang disebut ventral. Tahap akhir dari pembuatan alat serpih adalah penyempurnaan alat sesuai dengan yang diinginkan yaitu dengan panyerpihan kedua. Penyerpihan kedua ini biasanya untuk pembuatan tajaman dan peretusan-peretusan pada berbagai bagian baik pada seluruh bagian ataupun sebagian saja, retus-retus yang dilakukan secara menyeluruh pada bagian alat terkadang sampai menghilangkan dataran pukul sebagai bukti pelepasan dari batu inti. Tingkat penyerpihan baik kompleks maupun sederhana sangat menentukan produk yang dihasilkan dan tingkat teknologi yang telah dikenalnya.

Berdasarkan rangkaian pengerjaan serpih bilah tersebut, hal-hal yang dijadikan parameter tingkatan teknologi yang diterapkan untuk pembuatan alat disusun parameter yang meliputi cara pelepasan dari batu inti, ada tidaknya dataran pukul, bulbus, alur pukul, luka pukul, retak pukul, jumlah faset pangkasan pada dorsal, tipe pangkasan, tipe retus, lokasi retus, dan kemiringan retus.

Pelepasan dari batu inti dapat diketahui apakah secara langsung antara batu dengan batu lain yang lebih keras, atau tidak langsung yaitu dengan bantuan alat lain untuk dijadikan perforator. Ada tidaknya dataran pukul pada saat pelepasan dari batu inti, 
jika terdapat dataran pukul maka perlu diketahui dataran pukul ini lebar, sempit, berfaset, bersudut, ataukah datar/lurus. Ada tidaknya bulbus yang merupakan dampak dari pukulan keras untuk melepasan serpih dari batu inti dapat diketahui apakah bersifat negatif, menonjol/positif, datar, atau lebar, selain itu perlu diketahui ada tidaknya alur pukul, luka pukul, dan retak pukul akibat pelepasan serpih dari batu inti.

Pada bagian dorsal, hal-hal yang dijadikan parameter meliputi jumlah dan tipe pangkasan, selain itu pada bagian penyempurnaan perlu diketahui tentang tipe dan lokasi retus. Tipe pangkasan dapat dilakukan secara longitudinal, transversal, ortogonal, silang, sentripetal, sentrifugal, atau tidak beraturan. Sedangkan tipe retus meliputi tipe mikro, memanjang, melebar, cekungan, multi cekungan, mendatar, atau terjal. Lokasi retus meliputi bagian lateral, bilateral, atau distal dan kemiringan retus dapat dilakukan secara mendatar atau lurus.

\section{E. Bekas Penggunaan}

Variabel untuk mengetahui jejak-jejak penggunaan alat serpih adalah melalui perimping, kilap, kerusakan tajaman, dan sudut tajaman. Perimping pada serpih bilah sebagai indikasi pemakaian dapat diketahui intensifitas penggunaan alat, namun bisa saja tidak terdapat perimping yang berarti alat tersebut tidak dipakai. Apabila terdapat perimpin dapat diketahui pada bagian-bagian alat seperti pada distal, proksimal, lateral kanan, lateral kiri, bilateral, atau lateral distal. Kilap merupakan indikasi adanya penggunaan serpih sebagai alat memotong, di mana jejak-jejak bahan yang dipotong menempel pada serpih dapat terdapat pada bagian distal, proksimal, lateral kiri, bilateral, atau lateral distal. Kerusakan tajaman akibat pemakaian secara intensif dapat diamati pada bagian distal, lateral kiri, lateral kanan, bilateral, ataukah lateral distal. Sedangkan sudut tajaman untuk mengetahui fungsi alat dapat dibentuk sangat runcing, runcing, sedang, curam, atau tegak lurus.

\section{Pengolahan Data Dalam Komputer}

Pengolahan data ke dalam komputer dalam hal ini lebih dititikberatkan pada sajian statistik, dibagi dua katagori yaitu secara kuantitatif dan kualitatif. Kedua hal tersebut dapat disajikan masing-masing dalam bentuk tabel dan grafik melalui program komputer seperti Excel, Lotus, ataupun SPSS. Hal yang perlu dipersiapkan sebelum melakukan pengolahan data adalah penentuan variabel yang akan diolah seperti dari aspek bentuk baik secara tipologi maupun teknologi yang diterapkan pada alat; sebaran temuan secara horisontal (ruang), ataukah sebaran temuan secara kronologis. Selanjutnya berdasarkan penentuan variabel tersebut, pengolahan data dapat 
dilakukan. Beberapa kajian yang dapat diperdalam sesuai dengan struktur database teknik analisis serpih bilah adalah kajian secara kontekstual dan pola sebaran.

Kajian kontekstual meliputi beberapa hal yang dapat diungkap lebih lanjut seperti kajian aspek teknoekonomi melalui bekas-bekas pemakaian alat (Anggraeni, 1989); tingkat aktivitas pembuatan alat (bengkel atau konsumen/pengguna); atau kajian mengenai karakter industri litik yang dihasilkan untuk mengetahui kronologi (Widianto, 1981). Sedangkan kajian yang bertitikberat pada pola sebaran dapat dikaji secara ruang dan waktu.

\section{A. Tabel}

Penyajian ke dalam tabulasi merupakan proses mengubah data dari instrumen struktur database serpih bilah menjadi tabel-tabel data. Proses ini bisa dilakukan dalam berbagai tahap meliputi penentuan variabel sesuai dengan kebutuhan baik secara kualitatif maupun kuantitatif. Sebagai contoh dalam kajian teknoekonomi, hal-hal yang dijadikan parameter meliputi a) tipe alat, b) bekas-bekas penggunaan dan perbandingan terhadap bahan batuan yang sama, c) tingkat kerusakan tajaman yang didukung dengan hasil eksperimen, d) konteks temuan, dan e) analogi etnografis. Untuk tujuan tersebut mutlak diperlukan pengamatan fisik alat seperti tipe, bahan, dan ukuran. Ukuran alat yang perlu diketahui adalah panjang, tebal, besar sudut lateral, selain itu bentuk fisik, penampang, dan letak kerusakan tajaman juga menjadi parameter dalam kajian ini. Sedangkan untuk mengetahui bekas penggunaan alat, parameter yang dipakai adalah bentuk tajaman, besar sudut tajaman, tipe retus, dan lokasi retus.

Contoh tabel untuk mengetahui tingkat teknoekonomi serpih bilah.

\begin{tabular}{|c|c|c|c|c|c|c|}
\hline Tipe Alat & $\begin{array}{c}\text { Tajaman } \\
\text { tumpul } \\
\text { miring }\end{array}$ & $\begin{array}{c}\text { Panjang } \\
\text { dengan 1 sisi } \\
\text { tumpul }\end{array}$ & $\begin{array}{c}\text { Panjang } \\
\text { dengan 2 sisi } \\
\text { tumpul }\end{array}$ & Tranchet & $\begin{array}{c}\text { Patah dan } \\
\text { tidak } \\
\text { selesai }\end{array}$ & Jumlah \\
\hline & & & & & & \\
\hline
\end{tabular}

Contoh tabel untuk mengetahui fungsi alat.

\begin{tabular}{|c|c|c|c|c|c|}
\hline Tipe Alat & $\begin{array}{c}\text { Bentuk } \\
\text { Tajaman }\end{array}$ & $\begin{array}{c}\text { Besar sudut tajaman } \\
\text { (dalam derajat) }\end{array}$ & $\begin{array}{c}\text { Tipe } \\
\text { retus }\end{array}$ & $\begin{array}{c}\text { Lokasi } \\
\text { retus }\end{array}$ & Ciri lain \\
\hline & & & & & \\
\hline
\end{tabular}

Sementara dalam kajian pola sebaran baik ruang maupun waktu parameter yang dipakai meliputi tipe alat (data kualitatif) dan jumlah temuan pada masing-masing lokasi baik pada bentuk lahan (hasil survei kawasan) maupun kotak gali (hasil ckskavasi). Sebagai contoh dalam kajian ini adalah hasil ekskavasi pada situs gua (Nurani, 1997). 
Contoh tabel sebaran temuan.

\begin{tabular}{|l|l|l|l|l|l|l|}
\hline Tipe Alat & B-5 & C-6 & D-5 & E-6 & F-5 & Jumlah \\
\hline & & & & & & \\
\hline
\end{tabular}

\section{B. Grafik}

Penyajian grafik merupakan tingkat lanjutan setelah pembuatan tabel. Hal tersebut dimaksudkan untuk lebih mudah dimengerti dan ditafsirkan dengan mengamati frekuensi temuan. Dalam penyajiannya, grafik dapat disajikan dalam dua dimensi maupun tiga dimensi tergantung kebutuhan. Jenis grafik yang sudah tersedia pada masing-masing program komputer meliputi garis, batang, pie, area, titik-titik, surface, radar, gouhnut, pyramid, cone, dan cylinder. Untuk penyajian grafik sesuai dengan kebutuhan, hal-hal yang dipersiapkan terlebih dahulu adalah penentuan rumus berkaitan dengan sajian yang diharapkan dengan menggunakan jenis grafik yang sesuai. Sebagai contoh untuk mengetahui pemanfaatan lahan (tata ruang) gua perlu disajikan mengenai sebaran temuan sehingga didapat informasi tentang frekuensi temuan pada masing-masing kotak. Untuk itu perlu dibuat tabel tersendiri berupa datasheet untuk memunculkan grafik secara tiga dimensi. Hal tersebut dimaksudkan untuk memberi gambaran visual mengenai kuantitas temuan dalam suatu lahan gua yang tersedia.

Berikut dapat disajikan grafik secara tiga dimensi dengan menggunakan grafis jenis garis berdasarkan hasil penelitian di Gua Macan untuk kajian pemanfaatan lahan gua yang tersedia. Rumus yang disajikan dalam tabel datasheet ditetapkan dengan urutan angka pada colum, sedangkan untuk row/baris urutan abjad. Hal tersebut ditujukan untuk memberikan gambaran keletakan kotak gali yang digrid dengan nama B-5, D-2, D-3 dan seterusnya. Selanjutnya jumlah temuan dimasukkan pada masing-masing kotak gali secara koordinat, seperti untuk kotak D-2 ditemukan sejumlah 31 temuan alat, begitu seterusnya sesuai dengan jumlah temuan pada masing-masing kotak gali.

Tabel datasheet :

\begin{tabular}{|l|l|l|l|l|l|l|l|l|l|}
\hline & \multicolumn{1}{|c|}{$\mathbf{2}$} & \multicolumn{1}{|c|}{$\mathbf{4}$} & $\mathbf{4}$ & \multicolumn{1}{|c|}{$\mathbf{5}$} & $\mathbf{6}$ & $\mathbf{7}$ & $\mathbf{8}$ & $\mathbf{9}$ & $\mathbf{1 0}$ \\
\hline B & 0 & 0 & 0 & 2 & 0 & 0 & 0 & 0 & 3 \\
\hline C & 0 & 0 & 0 & 0 & 9 & 0 & 0 & 0 & 0 \\
\hline D & 31 & 25 & 11 & 15 & 0 & 3 & 0 & 0 & 0 \\
\hline E & 0 & 0 & 0 & 0 & 7 & 0 & 0 & 0 & 0 \\
\hline F & 0 & 0 & 0 & 7 & 0 & 0 & 0 & 0 & 0 \\
\hline
\end{tabular}

Berdasarkan datasheet tersebut akan tersaji grafik sebagai berikut. 


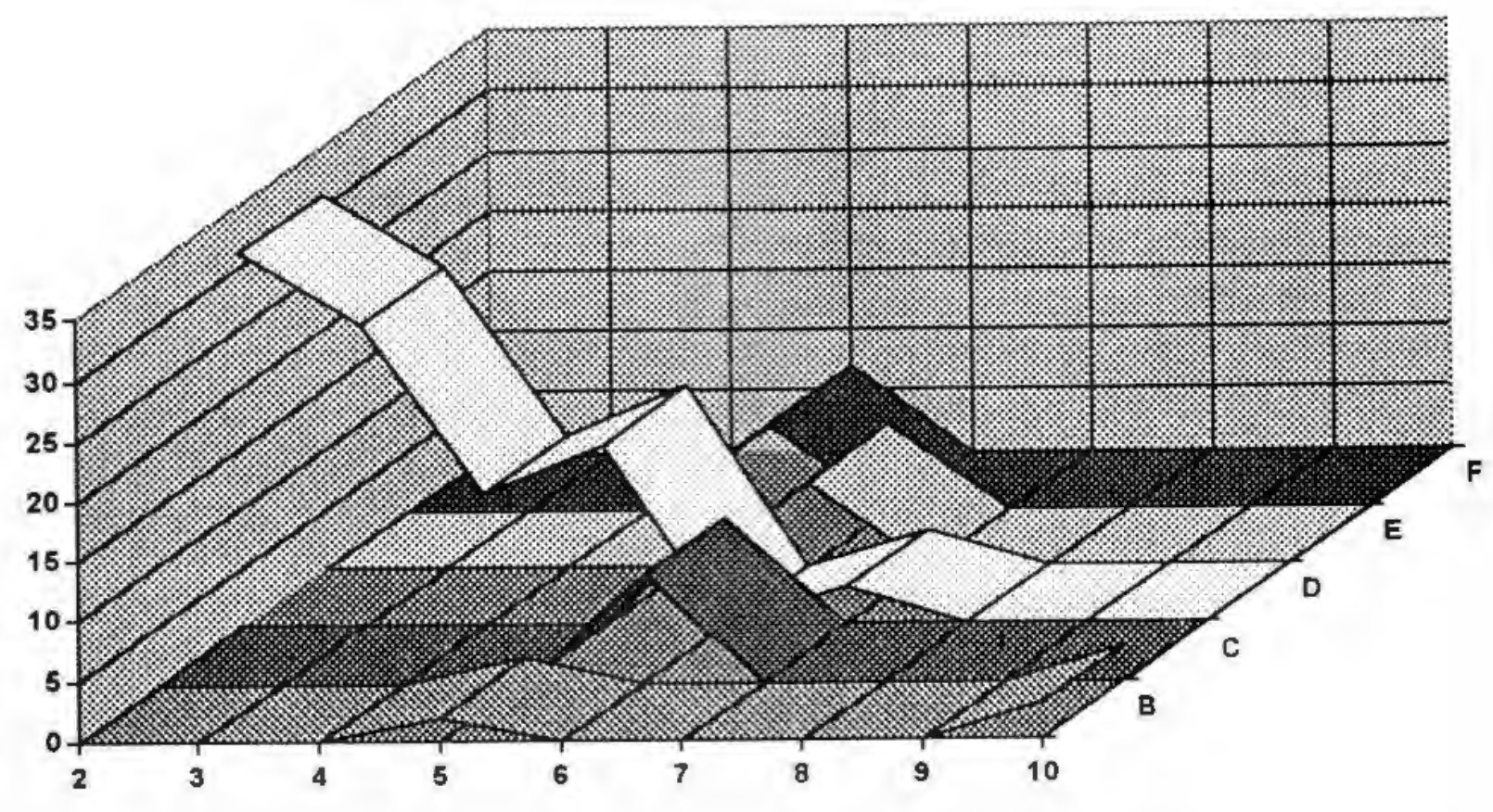

Grafik di atas dapat ditafsirkan frekuensi temuan alat paling banyak berada pada lahan bagian depan. Sementara lahan bagian tengah menunjukkan frekuensi temuan alat dalam jumlah merata. Sedangkan pada lahan bagian belakang semakin sedikit.

\section{Kesimpulan}

Berdasarkan uraian tersebut di atas, maka dapat disimpulkan hal-hal sebagai berikut :

1. Serpih bilah merupakan salah satu hasil budaya manusia masa prasejarah yang memiliki proses evolusi perkembangan teknologis. Sejak teknik paleolitik (batu tua) sampai teknik neolitik (batu muda), serpih bilah memiliki perkembangan baik dari segi teknologi, tipe, maupun morfologinya.

2. Penjabaran teknik analisis melalui struktur database diharapkan dapat memecahkan beberapa permasalahan untuk merekonstruksi cara hidup manusia masa prasejarah dengan tingkat teknologi yang dikenalnya. Selain itu dengan mengetahui tingkat teknologi, bahan baku yang digunakan, dan konteksnya akan terpecahkan bagaimana cara hidup manusia dalam menguasai dan beradaptasi terhadap lingkungan alam sekitarnya. Melalui struktur database pula diharapkan akan diketahui tingkat kemampuan manusia membuat alat dalam waktu ribuan tahun dengan bahan yang tersedia dan tingkat teknologi yang diterapkan.

3. Pengolahan data dalam komputer berdasarkan struktur database dan penentuan parameter pada beberapa aspek akan mudah dibaca dengan sajian visual berupa tabel dan grafik. 


\section{KEPUSTAKAAN}

Anggraeni, 1989. Mikrolit Sebagai Salah Satu Pendukung Sistem Teknoekonomi Budaya Toala. Skripsi Fakultas Sastra, Universitas Gajah Mada.

Crabtree, Don E. 1972, An Introduction to Flintworking. Idaho : Occasional Papers of The Museum Idaho State University.

Greisser, Sally T. and Payson D. Sheets, 1979. Raw Materials as a Functional Variable in Use-Wear Studies. In Brian Hayden (ed.), Lithic Use-Wear Analysis. New York: Academic Press. pp. 289-296.

Hodges, Henry, 1964. Artifacts An Introduction to Early Materials and Technology. London: John Baker Publishers Ltd.

Nurani, I. A. (1997). Bentuk Pemanfaatan Lahan Gua Macan Suatu Kajian Pemukiman Skala Mikro. Berkala Arkeologi, 17(2), 8-25. https://doi.org/10.30883/jba.v17i1.758

Simanjuntak, Truman, 1994. Kehidupan Prasejarah di Pegunungan Seribu. Makalah dipresentasikan dalam Ceramah Ilmiah Pengembangan Budaya Pegunungan Seribu. Pacitan : 29 Januari.

Simanjuntak, Truman dan Retno Handini, 1997. Laporan Penelitian Song Keplek tahun 1996 dan 1997. Jakarta: Bidang Prasejarah Pusat Penelitian Arkeologi Nasional. Belum diterbitkan.

Soetoto, 1984. Materi Penyusun Tubuh Bumi. Yogyakarta: Ranggon Studi Haasye Bodri Jooswi.

Sutton, Mark Q., 1996. Archaeological Laboratory Methods: An Introduction. Iowa: Kendall/ Hunt Publishing Company.

Widianto, Harry, 1983. Paleolitik Kali Oyo dalam Kronologi Pertanggalan Plestosen. Skripsi Fakultas Sastra Universitas Gadjah Mada.

Widianto, Harry, 1984. Temuan Alat Paleolitik dari Situs Mulyorejo. Cepu. Artefak hlm. 30--39. Buletin Himpunan Mahasiswa Arkeologi Fakultas Sastra Universitas Gadjah Mada. 